\title{
MANAJEMEN PENINGKATAN MUTU GURU MATEMATIKA
}

\author{
Ara Hidayat \\ UIN Sunan Gunung Djati Bandung, arahidayat@uinsgd.ac.id
}

\begin{abstract}
Abstrak
Penelitian ini bertitik tolak dari suatu asumsi atau pandangan yang melihat adanya perbedaan kompetensi individu, kreativitas individu, pimpinan, dan faktor lingkungan dengan kinerja atau produktivitas lembaga pendidikan. Pemikiran ini rasional dan logis karena kompetensi individu dalam suatu produktivitas dipengaruhi oleh kreativitas pimpinan, dan faktor lingkungan dimana mereka beraktivitas. Tujuan umum penelitian ini adalah untuk mendapatkan gambaran tentang profil guru matematika dan kebijakan kepala sekolah dalam upaya peningkatan kualitas diri pendidik dan secara khusus penelitian ini difocuskan pada kompetensi individu, kreativitas pimpinan dan faktor lingkungan sebagai moderator atau motivator terhadap : Prestasi Akademik, Sustainabilitas dan kinerja. Penelitian yang dilakukan berupa penelitian kualitatif, pengumpulan data dilakukan dengan observasi dan penyebaran angket. Hasil penelitian menunjukkan bahwa mutu guru matematika perlu ditingkatkan, kebijakan kepala sekolah dalam upaya meningkatkan mutu guru mateamtika termasuk pada kategori cukup, prestasi akademik, kinerja dan lingkungan perlu dioptimalkan dalam meningkatkan mutu guru matematika.

Kata Kunci : Guru, Manajemen, Matematika, MBS, Mutu.
\end{abstract}

\begin{abstract}
This research is based on a principle or view that sees individual personality differences, individual creativity, leadership, and environmental factors with the performance or productivity of educational institutions. This thinking is rational and logical because of the individual's competence in a productivity by the leaders, and the environmental factors in which they move. The general purpose of this research is to get an overview of the profile of math teacher and principal's strategy in improving the quality of self and professionalism as a moderator or motivator on: Academic Achievement, Sustainability and Performance. Research conducted qualitative research, completion of data is done by observation and dispersion of questionnaire. The result of the research showed improvement of mathematics teacher quality. Increased learning achievement of mateamtika teachers included in the category enough, academic achievement, performance and environment.
\end{abstract}

Keywords: Teachers, Management, Mathematics, SBM, Quality. 


\section{PENDAHULUAN}

Matematika merupakan salah satu mata pelajaran yang diajarkan pada semua jenjang pendidikan. Matematika merupakan ratu dan pelayan ilmu pengetahuan, matematika disebut ratu ilmu karena matematika menjadi sumber bagi ilmu yang lain. Banyak cabang pengetahuan yang dikembangkan dari konsep-konsep matematika. Sedangkan matematika sebagai pelayan ilmu berarti matematika tumbuh dan berkembang untuk dirinya sendiri sebagai suatu ilmu dan sebagai penyedia jasa layanan untuk pengembangan ilmu-ilmu lainnya (Suherman, 2001). Matematika banyak diaplikasikan pada cabang ilmu yang lain, namun masih banyak siswa yang tidak menganggap matematika penting karena mereka tidak mengetahui apa manfaat dari konsep matematika yang dipelajari. Matematika yang dianggap abstrak dapat lebih dibentuk sedemikian rupa sehingga lebih konkret dan jelas dengan menghubungkan konsep matematika dengan kehidupan sehari-hari siswa, atau dapat juga digunakan media teknologi informasi maupun media pembelajaran lainnya. Pada hal ini peran guru matematika menjadi sangat penting untuk dapat mengkontekstualkan konsep matematika yang diajarkan.

Salah satu upaya membuat matematika menjadi terlihat lebih konkret adalah dengan menggunakan aplikasi/software-software dan melakukan pengembangan pembelajaran matematika. Guna menguasai aplikasi teknologi dan model-model pembelajaran yang up to date guru perlu mengembangkan kompetensi diri.

Peningkatan kompetensi guru dipengaruhi oleh banyak hal diantaranya peran dari kepala sekolah, lingkungan dan lain-lain.

Penelitian ini bertitik tolak dari suatu asumsi atau pandangan yang melihat adanya perbedaan kompetensi individu, kreativitas individu, pimpinan, dan faktor lingkungan dengan kinerja atau produktivitas lembaga pendidikan. Pemikiran ini rasional dan logis karena kompetensi individu dalam suatu produktivitas dipengaruhi oleh kreativitas pimpinan, dan faktor lingkungan dimana mereka beraktivitas. Tujuan umum penelitian ini adalah untuk mendapatkan gambaran tentang profil guru matematika dan kebijakan kepala sekolah dalam upaya peningkatan kualitas diri pendidik dan secara khusus penelitian ini difocuskan pada kompetensi individu, kreativitas pimpinan dan faktor lingkungan sebagai moderator atau motivator terhadap : Prestasi Akademik, Sustainabilitas dan kinerja.

Peningkatan efisiensi terutama diperoleh dari keleluasaan yang diberikan untuk mengelola sumberdaya partisipasi masyarakat dan penyederhanaan birokrasi. Kemudian. Peningkatan mutu dapat diperoleh, antara lain melalui partisipasi orang tua terhadap sekolah, fleksibilitas pengelolaan sekolah dan kelas, peningkatan profesionalisme guru dan kepala sekolah, berlakunya sistem intensif serta disintensif. Sedang, peningkatan pemerataan bisa diperoleh melalui peningkatan partisipasi masyarakat yang memungkinkan pemerintah lebih bisa berkonsentrasi pada kelompok tertentu. Hal ini dimungkinkan karena pada sebagian masyarakat tumbuh rasa kepemilikan yang tinggi terhadap sekolah.

Diantara manfaat MPMGM (Managemen Peningkatan Mutu Guru matematika) adalah memberikan kebebasan dan 'kekuasaan' yang besar 
kepada sekolah, yang tentu saja disertai dengan seperangkat tanggung jawab. Pemberian otonomi kepada sekolah mengindikasikan sebuah tanggung jawab pengelolaan sumber daya pengembangan dan strategi peningkatan mutu guru matematika.

Pemberian kesempatan kepada guru untuk menyusun silabus; guru dituntut bahkan didorong untuk berinovasi, dengan melakukan eksperimentasi-eksperimentasi di dalam pembelajaran. Melalui penyusunan silabus dan bahan ajar yang efektif, yang sesuai dengan tuntutan zaman.

\section{Karakteristik MPMGM} sebagaimana managemen berbasis sekolah adalah sebagaimana karakteristik dalam sekolah efektif yaitu mencakup Output berupa prestasi akademik (academic, achivement) dan ouput berupa prestasi non-akademik (non-academic achivement). Proses berupa Proses Belajar Mengajar yang Efektivitasnya Tinggi, Kepemimpinan Sekolah yang Kuat, Lingkungan Sekolah yang Aman dan Tertib, Pengelolaan Tenaga Kependidikan yang efektif, Sekolah memiliki Budaya Mutu, Sekolah memiliki "Teamwork" yang kompak, Cerdas, dan Dinamis, Sekolah memiliki Kewenangan (kemandirian), Partisipasi yang Tinggi dari Warga dan Masyarakat, Sekolah memiliki Keterbukaan (Transparansi) Manajemen, Sekolah memiliki Kemauan untuk Berubah (psikologis dan pisik), Sekolah Melakukan Evaluasi dan Perbaikan Secara Berkelanjutan, Sekolah Responsi dan antisipatif terhadap Kebutuhan, Memiliki komunikasi yang baik, Sekolah memiliki akuntabilitas, dan Sekolah memiliki Kemampuan Manajemen Sustainabilitas.
Sedangkan Input Pendidikan mencakup memiliki kebijakan, tujuan dan sasaran Mutu guru matematika yang jelas, Sumberdaya Tersedia dan Siap, kompeten dan berdedikasi tinggi, Memiliki Harapan Prestasi yang tinggi, fokus pada siswa dan tercapainya visi misi sekolah.

\section{KAJIAN TEORI}

Konsep dasar MPMGM diadopsi dari managemen berbasis sekolah. Secara terperinci tujuan penerapan MPMBS dapat dijabarkan (Mulyasa, 2002) sebagai berikut, meningkatkan mutu pendidikan melalui kemandirian dan inisiatif sekolah dalam mengelola dan memberdayakan sumber daya yang tersedia, meningkatkan kepedulian warga sekolah dan masyarakat dalam menyelenggarakan pendidikan melalui pengambilan keputusan bersama, meningkatkan tanggung jawab sekolah kepada orang tua peserta didik, masyarakat, dan pemerintah tentang mutu sekolahnya, meningkatkan kompetisi yang sehat antarsekolah tentang mutu pendidikan yang akan tercapai. Managemen berbasis sekolah yang menekankan pada otonomi dan pengambilan keputusan partisipatif. Otonomi dapat diartikan sebagai kewenangan/kemadirian, yaitu kemandirian dalam mengatur dan mengurus dirinya sendiri, dan merdeka/tidak tergantung. Kemandirian dalam program dan pendanaan merupakan tolok ukur utama kemandirian sekolah. Pada gilirannya, kemandirian yang berlangsung secara terus menerus akan menjamin kelangsungan hidup dan perkembangan sekolah (sustainabilitas). Istilah otonomi juga sama dengan istilah "swa", misalnya 
swasembada, swadana, swakarya, dan swalayan. Jadi otonomi sekolah adalah kewenangan sekolah untuk mengatur dan mengurus kepentingan warga sekolah menurut prakarsa sendiri berdasarkan aspirasi warga sekolah sesuai dengan peraturan sendiri berdasarkan aspirasi warga sekolah sesuai dengan peraturan perundangundangan pendidikan nasional yang berlaku. Tentu saja kemandirian yang dimaksud harus didukung oleh sejumlah kemampuan, yaitu kemampuan mengambil keputusan yang terbaik, kemampuan berdemokrasi/menghargai perbedaan pendapat, kemampuan memobilisasi sumberdaya, kemampuan memilih cara pelaksanaan yang terbaik, kemampuan berkomunikasi dengan cara yang efektif, kemampuan memecahkan persoalan-persoalan sekolah, kemampuan adaptif dan antisipatif, kemampuan bersinergi dan berkolaborasi, dan kemampuan memenuhi kebutuhan sendiri.

Fleksibilitas dapat diartikan sebagai keluwesan-keluwesan yang diberikan kepada sekolah untuk mengelola, memanfaatkan dan memberdayakan sumberdaya sekolah seoptimal mungkin untuk meningkatkan mutu sekolah, maka sekolah akan lebih lincah dan tidak harus menunggu arahan dari atasan untuk mengelola, memanfaatkan dan memberdayakan sumberdaya. Dengan cara ini, sekolah akan lebih responsif dan lebih cepat dalam menanggapi segala tantangan yang dihadapi. Namun demikian, keluwesankeluwesan yang dimaksud harus tetap dalam koridor kebijakan dan peraturan perundang- undangan yang ada.

Peningkatan partisipasi yang dimaksud adalah penciptaan lingkungan yang terbuka dan demokratik, dimana warga sekolah (guru, siswa, karyawan) dan masyarakat (orang tua siswa, tokoh masyarakat, ilmuwan, usahawan, dan sebagainya) didorong untuk terlibat secara langsung dalam penyelenggaraan pendidikan, mulai dari pengambilan keputusan, pelaksanaan, dan evaluasi pendidikan yang diharapkan dapat meningkatkan mutu pendidikan. Hal ini dilandasi oleh keyakinan bahwa jika seseorang dilibatkan (berpartisipasi) dalam penyelenggaraan pendidikan, maka yang bersangkutan akan mempunyai "rasa memiliki" terhadap sekolah, sehingga yang bersangkutan juga akan bertanggung jawab dan berdedikasi sepenuhnya untuk mencapai tujuan sekolah. Singkatnya makin besar tingkat partisipasi, makin besar pula rasa memiliki; makin besar rasa memiliki, makin besar pula rasa tanggung jawab; dan makin besar rasa tanggung jawab, makin besar pula dedikasinya. Tentu saja pelibatan warga sekolah dalam penyelenggaraan sekolah harus mempertimbangkan keahlian, batas kewenangan, dan relevansinya dengan tujuan partisipasi. Peningkatan partisipasi warga sekolah dan masyarakat dalam penyelenggaraan sekolah akan mampu menciptakan keterbukaan, kerjasama yang kuat, akuntabilitas, dan demokrasi pendidikan. Keterbukaan yang dimaksud adalah keterbukaan dalam program dan keuangan. Kerjasama yang dimaksud adalah adanya sikap dan perbuatan lahiriyah kebersamaan/kolektif untuk meningkatkan mutu sekolah. Kerjasama sekolah yang baik ditunjukkan oleh hubungan antar warga sekolah yang erat, hubungan sekolah dan masyarakat erat, dan adanya kesadaran bersama bahwa output sekolah merupakan hasil kolektif teamwork yang kuat dan 
cerdas. Akuntabilitas sekolah adalah pertanggung jawaban sekolah kepada warga sekolahnya, masyarakat dan pemerintah melalui pelaporan dan pertemuan yang dilakukan secara terbuka. Sedangkan demokrasi pendidikan adalah kebebasan yang terlembagakan melalui musyawarah dan mufakat dengan menghargai perbedaan, hak asasi manusia serta kewajiban dalam rangka untuk meningkatkan mutu pendidikan.

Dengan pengertian diatas, maka sekolah memiliki kewenangan (kemandirian) lebih besar dalam mengelola sekolahnya (menetapkan sasaran peningkatan mutu, menyusun rencana peningkatan mutu, melaksanakan rencana peningkatan mutu, dan melakukan evaluasi pelaksanaan peningkatan mutu), memiliki fleksibilitas pengelolaan sumber daya sekolah, dan memiliki partisipasi yang lebih besar dari kelompok yang berkepentingan dengan sekolah. Dengan kepemilikan ketiga hal ini, maka sekolah dalam hal ini berfokus pada mutu guru matematika yang ingin dicapai, sebagai salah satu sumber daya yang perlu dikembangkan.

Sumber daya yang harus didesentralisasikan ke sekolah yaitu power/authority, knowledge, information dan reward (Wohlstetter \& Mohrman, 1994)

a. Kekuasaan/kewenangan (power/authority) harus didesentralisasikan ke sekolahsekolah secara langsung yaitu melalui dewan sekolah. Sedikitnya terhadap tiga bidang penting yaitu budget, personnel dan curriculum. Termasuk dalam kewenangan ini adalah menyangkut pengangkatan dan pemperhentian kepala sekolah, guru dan staff sekolah. b. Pengetahuan (knowledge) juga harus didesentralisasikan sehingga sumberdaya manusia di sekolah mampu memberikan kontribusi yang berarti bagi kinerja sekolah. Pengetahuan yang perlu didesentralisasikan meliputi: keterampilan yang terkait dengan pekerjaan secara langsung (job skills), keterampilan kelompok (teamwork skills) dan pengetahuan keorganisasian (organizational knowledge). Keterampilan kelompok diantaranya adalah pemecahan masalah, pengambilan keputusan dan keterampilan berkomunikasi. Termasuk dalam pengetahuan keorganisasian adalah pemahaman lingkungan dan strategi merespon perubahan.

c. Hakikat lain yang harus didensentralisasikan adalah informasi (information). Pada model sentralistik informasi hanya dimiliki para pimpinan puncak, maka pada model MBS harus didistribusikan ke seluruh constituent sekolah bahkan ke seluruh stakeholder. Apa yang perlu disebarluaskan? Antara lain berupa visi, misi, strategi, sasaran dan tujuan sekolah, keuangan dan struktur biaya, isu-isu sekitar sekolah, kinerja sekolah dan para pelanggannya. Penyebaran informasi bisa secara vertikal dan horizontal baik dengan cara tatap muka maupun tulisan.

d. Penghargaan (reward) adalah hal penting lainnya yang harus didesentralisasikan. Penghargaan bisa berupa fisik maupun non-fisik yang semuanya didasarkan atas prestasi kerja. Penghargaan fisik bisa berupa pemberian hadiah seperti uang. Penghargaan non-fisik berupa kenaikan pangkat, melanjutkan pendidikan, mengikuti 
seminar atau konferensi dan penataran.

Sementara Depdiknas (Depdiknas, 2001)merumuskan 9 hal yang dapat didesentralisaskan ke sekolah yaitu:

a. Perencanaan dan evaluasi program sekolah. Sekolah diberi kewenangan untuk melakukan perencanaan sesuai dengan kebutuhannya, misalnya kebutuhan untuk meningkatkan mutu sekolah. Sekolah juga diberi wewenang untuk melakukan evaluasi, khususnya evaluasi internal atau evaluasi diri.

b. Pengelolaan kurikulum. Sekolah dapat mengembangkan, namun tidak boleh mengurangi isi kurikulum yang berlaku secara nasional yang dikembangkan oleh Pemerintah Pusat. Sekolah juga diberi kebebasan untuk mengembangkan kurikulum muatan lokal.

c. Pengelolaan proses belajar mengajar. Sekolah diberi kebebasan untuk memilih strategi, metode dan teknik pembelajaran dan pengajaran yang paling efektif sesuai dengan karakteristik mata pelajaran, karakteristik siswa, karakteristik guru dan kondisi nyata sumber daya yang tersedia di sekolah.

d. Pengelolaan ketenagaan. Pengelolaan ketenagaan mulai dari analisis kebutuhan perencanaan, rekrutmen, pengembangan, penghargaan dan sangsi, hubungan kerja hingga evaluasi kinerja tenaga kerja sekolah dapat dilakukan oleh sekolah kecuali guru pegawai negeri yang sampai saat ini masih ditangani oleh birokrasi di atasnya.

e. Pengelolaan peralatan dan perlengkapan. Pengelolaan fasilitas seharusnya dilakukan oleh sekolah mulai dari pengadaan, pemeliharaan dan perbaikan hingga pengembangannya. Hal ini didasari oleh kenyataan bahwa sekolahlah yang paling mengetahui kebutuhan fasilitas baik kecukupan, kesesuaian dan kemutakhirannya terutama fasilitas yang sangat erat kaitannya secara langsung dengan proses belajar mengajar.

f. Pengelolaan keuangan. Pengelolaan keuangan, terutama pengalokasian/penggunaan uang sudah sepantasnya dilakukan oleh sekolah. Sekolah juga harus diberi kebebasan untuk melakukan kegiatan-kegiatan yang mendatangkan penghasilan, sehingga sumber keuangan tidak semata-mata tergantung pada pemerintah.

g. Pelayanan siswa. Pelayanan siswa mulai dari penerimaan siswa baru, pengembangan, pembinaan, pembimbingan, penempatan untuk melanjutkan sekolah atau untuk memasuki dunia kerja hingga pengurusan alumni dari dulu telah didesentralisasikan. Yang diperlukan adalah peningkatan intensitas dan ekstensitasnya.

h. Hubungan sekolah dan masyarakat. Esensi hubungan sekolah dan msyarakat adalah untuk meningkatkan keterlibatan, kepedulian, kepemilikan dan dukungan dari masyarakat, terutama dukungan moral dan finansial yang dari dulu telah didesentralisasikan. Yang diperlukan adalah peningkatan intensitas dan ekstensitasnya.

i. Pengelolaan iklim sekolah. Iklim sekolah yang kondusif-akademik merupakan prasyarat bagi terselenggaranya proses belajar mengajar yang efektif. Lingkungan sekolah yang aman dan tertib, 
optimisme dan harapan yang tinggi dari warga sekolah, kesehatan sekolah dan kegiatan-kegiatan yang terpusat pada siswa adalah contoh iklim sekolah yang dapat menumbuhkan semangat belajar siswa. Iklim sekolah sudah merupakan kewenangan sekolah dan yang diperlukan adalah peningkatan intensitas dan ekstensitasnya.

\section{METODE PENELITIAN}

\section{Jenis Penelitian}

Pendekatan penelitian yang digunakan adalah pendekatan kualitatif. Penelitian ini termasuk pada penelitian deskriptif.

\section{Waktu dan Tempat Penelitian}

Penelitian ini dilakukan di Madrasah Tsanawiyah Swasta di Cibiru Kota Bandung.

\section{Subjek Penelitian}

Pemilihan subjek dilakukan
menggunakan criterion based
selection. Adapun teknik yang
digunakan adalah snow ball sampling.
Penelitian ini melibatkan guru
matematika MTs, kepala Sekolah,
warga sekolah lainnya.

\section{Prosedur Penelitian}

$$
\begin{aligned}
& \text { Penelitian dilakukan dengan } \\
& \text { melakukan observasi terhadap } \\
& \text { lingkungan sekolah dan penyebaran } \\
& \text { angket yang berkaitan dengan } \\
& \text { kebijakan pimpinan (kepala sekolah) }
\end{aligned}
$$

dalam upaya peningkatan kualitas diri guru matematika.

\section{Data, Instrumen, dan Teknik Pengumpulan Data}

Jenis data yang digunakan adalah data kualitatif dari hasil observasi dan angket. Instrumen yang digunakan antara lain adalah pedoman observasi, dan lembar angket terbuka yang meliputi indicator kompetensi individu guru matematika, kreativitas pimpinan, prestasi akademik, sustainabilitas, kinerja dan faktor lingkungan..

\section{Teknik Analisis Data}

Analisis data yang dilakukan melalui beberapa tahap pengolahan data yang meliputi, proses penyuntingan, pengkodean, tabulasi, analisis data, dan terakhir menginterpretasikan hasil analisis data yang telah dilakukan

\section{HASIL DAN PEMBAHASAN}

Hasil analisis data penelitian dapat dilihat pada poin-poin berikut:

1. Kompetensi diri Guru Matematik Kemampuan TI menjadi salah satu tuntutan guru pada era ini, namun berdasarkan hasil penelitian diketahui bahwa $25 \%$ guru matematika mengalami hambatan dalam penggunaan computer.berbagai alasan mengemuka, diantarnya guru merasa memiliki motivasi yang rendah untuk mengikuti seminar/ workshop selain untuk keperluan kenaikan pangkat tidak 
menguasai computer, dan tidak ada waktu karena banyaknya administrasi pembelajaran yang harus dikerjakan. Hal ini juga diperkuat dengan presentasi guru yang telah mengenal softwaresoftware matematika hanya sekitar $11,4 \%$, dan sisanya belum pernah menggunakan software matematika, salah satu yang menjadi penyebabnya adalah belum pernah mengikuti pelatihan penggunaan software matematika. Guru matematika yang pernah mengikuti seminar, pelatihan, lokakarya lainnya sebagai upaya pengembangan diri tercatat $2,84 \%$.

2. Kreativitas Pimpinan

Kreativitas kepala sekolah dalam peningkatan mutu guru pendidikan matematika masuk pada kategori cukup, hal ini juga dapat dilihat dari kesempatan yang diberikan kepala sekolah agar guru-guru meningkatkan kompetensi dengan mengikuti seminar, pelatihan/workshop dan melajutkan pendidikan baik formal dan informal.

3. Prestasi Akademik dan Kinerja

Prestasi yang dicapai guru matematika diantaranya adalah telah lulus program sertifikasi guru matematika, prestasi akademik dan kinerja lain yang lebih spesifik dibidang matematika masih sangat perlu diupayakan, demikian halnya dengan prestasi siswanya. Hal ini menunjukkan bahwa mutu guru juga sangat menentukan mutu siswanya.

4. Sustainable

Upaya yang berkelanjutan dari pihak sekolah untuk meningkatkan mutu guru matematika dilakukan dengan banyak mengundang para pakar untuk memberikan pelatihan atau menjadi narasumber seminar dengan materi yang disesuaikan dengan kebutuhan para guru serta dilakukan secara rutin.

5. Faktor Lingkungan

Faktor likungan sekolah juga sangat menentukan menentukan peningkatan mutu guru matematika, kepedulian orang tua terhadap siswa juga akan membuat guru lebih termotivasi memberikan yang terbaik. Sinergi dari guruguru se-MGMP juga akan sangat mempengaruhi iklim peningkatan kualitas diri guru matematika.

\section{SIMPULAN DAN SARAN}

\section{Kesimpulan}

a. Profil guru matematika menunjukkan bahwa peningkatan kompetensi diri guru matematika masih sangat perlu ditingkatkan, khususnya dalam penguasaan penggunaan teknologi informasi dan media pembelajaran yang sesuai dengan perkembangan zaman.

b. Kepala sekolah dituntut untuk dapat lebih memotivasi guru-guru matematika untuk lebih berpartisipasi aktif dalam kegiatan pengembangan kompetensi diri, atau bekerjasa dengan perguruan tinggi atau pihak lainnya untuk 
melakukan pendampingan atau pelatihan-pelatihan yang rutin diagendakan.

\section{Saran}

a. Proses pengambilan kebijakan kepala sekolah dalam upaya meningkatkan mutu guru matematika dilingkungan kelompok kerja sekolah yang disepakati bersama untuk menjadwalkan rutin dengan mendatangkan para pakar pembelajaran matematika melalui lesson study matematika dan kegiatan lainnya.

b. Perlu dilakukan penelitian lebih lanjut mengenai seberapa signifikan korelasi atau pengaruh lingkungan sekolah, kepemimpinan kepala sekolah dan factor lainnya terhadap mutu guru matematika.

c. Perlu dilakukan penelitian lebih lanjut mengenai upaya peningkatan mutu guru matematika yang lebih spesifik terhadap 4 kompetensi dasar guru.

\section{DAFTAR PUSTAKA}

Depdiknas. (2001). Manajemen

Peningkatan Mutu Berbasis

Sekolah Buku Konsep dan

Pelaksanaan . Jakarta:

Balitbang Depdiknas.

Mulyasa, E. (2002). Manajemen Berbasis Sekolah, Konsep Strategi dan Implikasinya. Bandung: PT Remaja Rosdakarya.

Suherman, E. (2001). Strategi Pembelajaran Matematika Kontemporer. Bandung: JICA.

Wohlstetter, P., \& Mohrman, S. (1994). School Based Management: Promise and proses. Finance Brief, Consortium for Policy Research in Education New Brunswick. NJ: Rutgers University. 
